\title{
KEDUDUKAN HUKUM ANAK ASTRA DALAM HUKUM WARIS ADAT BALI SETELAH ORANG TUA BIOLOGISNYA KAWIN SAH
}

\author{
Agus Suarnegara, I Made Suwitra, I Ketut Sukadana \\ Fakultas Hukum Universitas Warmadewa, Denpasar-Bali, Indonesia \\ agussuarnegara12@gmail.com, Madesuwitra27@gmail.com, Sukadanaketut1966@gmail.com
}

\begin{abstract}
Abstrak
Kedudukan Hukum Anak Astra dalam hukum waris adat Bali setelah orang tua kawin sah akan mengikuti ayahnya. Banyak ditemukan dalam kehidupan masyarakat, adanya kejadian anak yang lahir dari wanita yang belum berada di dalam ikatan perkawinan yang sah sehingga dapat menimbulkan masalah. Penelitian ini bertujuan menjelaskan kedudukan Hukum Anak Astra setelah berlakunya Undang-Undang Nomor 1 Tahun 1974 tentang Perkawinan dan mendeskripsikan Hak Waris Anak Astra dalam Hukum adat Bali setelah orang tua biologisnya kawin sah. Penelitian ini menggunakan penelitian normatif dengan mengkaji peraturan Perundang-Undangan yang berlaku dengan mengaitkan kenyataan yang ada di lapangan, berkaitan hal ini tentu pendekatan yang tepat adalah pendekatan Perundang-Undangan. Adapun bahan hukum yang digunakan adalah bahan hukum primer dan sekunder. Selanjutnya bahan hukum yang terkumpul diolah dan dianalisis dengan menggunakan teknik analisis interpretasi sistematis. Hasil penelitian menunjukkan bahwa Kedudukan anak astra setelah berlakunya UU No. 1 Tahun 1974, secara hukum hanya mempunyai hubungan perdata dengan ibunya dan keluarga ibunya. Hak Anak Astra Dalam Hukum adat Bali Setelah Orang Tua Biologisnya Kawin Sah di Bali adalah setelah anak astra itu lahir dalam perkawinan yang sah maka hak dan statusnya menurut ke ayahnya (purusa).
\end{abstract}

Kata kunci : Anak Astra, Hukum Waris Adat Bali, Kedudukan Anak, Kawin Sah

\begin{abstract}
The legal position of Astra's children in Balinese traditional inheritance law after their parents are legally married will follow their father. Many are found in community life, the incidence of children born to women who are not yet in a legal marriage bond so that it can cause problems. This study aims to explain the legal position of Astra's children after the enactment of Law Number 1 of 1974 concerning Marriage and to describe the inheritance rights of Astra's children in Balinese customary law after their biological parents are legally married. This study used normative research by examining the prevailing laws and regulations by relating the realities in the field, in this regard, of course, the right approach is the Legislative Approach. The legal materials used were primary and secondary legal materials. Furthermore, the collected legal materials are processed and analyzed using systematic interpretation analysis techniques. The results showed that the position of Anak Astra after the enactment of Law no. 1 of 1974, legally only has a civil relationship with his mother and his mother's family. The rights of Astra's children in Balinese customary law After their biological parents get married legally in Bali, it is after Astra's child is born in a legal marriage that his rights and status are according to his father (purusa).
\end{abstract}

Keywords: Child status, Balinese Customary Inheritance Law, Astra's children, Legally Married

\section{PENDAHULUAN}

Hidup bersama terjadi pada orang-orang dari berbagai jenis dan telah memenuhi persyaratan pernikahan, mereka sudah bisa disebut pasangan suami istri. Menurut Hukum Adat di Bali, jika anak dilahirkan sebelum upacara perkawinan dilaksanakan disebut anak di luar nikah, di mana istilah anak di luar nikah dapat dibagi menjadi (dua), yaitu seorang anak dengan sebutan anak bebinjat dan astra anak. Anak Bebinjat dan Anak Astra memiliki perbedaan, dimana Anak Bebinjat merupakan anak di luar pernikahan, lazimnya tak diketahui bapaknya dan tak diakui. Sedangkan Anak Astra merupakan anak di luar pernikahan, yang mana kasta laki-laki yang menurunkan lebih tinggi dari kasta perempuan. Pada keadaan tersebut tidak terjadi perkawinan secara sah namun bapak anak ini diketahui (Soeripto, 1973). Jika perempuan hamil terlebih dahulu sebelum dilaksanakannya pernikahan, jadi pada keadaan tersebut pernikahan bisa terus dilaksanakan asal pihak pria sudah tahu 
tentang kehamilan perempuan tersebut, dimana anak yang lahir tersebut adalah anak sah (Soeripto, 1973:30).

Warga Bali mempercayai sistem kekeluargaan patrilineal yaitu posisi pihak laki-laki dominan dibandingkan dengan pihak perempuan, karena itu anak astra memiliki posisi setara dengan anak sah tentang hubungan antara ibu maupun keluarga ibu (Saragih, 1984). Namun saat ini, kerap kali kelahiran anak astra dipublikasikan atau mendapat pengesahan dari orang tua anak tersebut (bapak aslinya). Setelah mendapatkan pengesahan dan pengakuan dari bapak aslinya kepada anak astra itu, hingga munculah hubungan hukum terhadap bapak anak itu. Berdasarkan kelompok etnik dan suku bangsa Indonesia memiliki hukum waris adat yang memiliki sifat pluralistik. Lazimnya, hal tersebut dikarenakan garis keturunan yang tidak sama, yang menjadikan dasar sistem suku bangsa dan kelompok etnik. Adapun perkaranya yaitu apakah terdapat kemiripan antara hukum waris adat yang dianut dan tetapkah itu dianut walau mereka menetap di luar daerah asalnya (Soekanto, 1986). Sebelumnya perlu diingat bahwa masyarakat yang beragama hindu tidak saja berada di Bali namun terdapat di daerah lain transmigrasi. Oleh karena itu hukum waris untuk warga Hindu yaitu refleksi dari agama Hindu yang dianutnya, jadi susah membedakan antara menurut agama Hindu dan menurut adat (Hadikusuma.H, 1996).

Berdasarkan hukum waris yang berfungsi sebagai subjek yaitu pewaris dan ahli waris, begitupun dengan hukum waris adat. Pewaris merupakan orang yang meninggalkan ataupun menyerahkan harta warisan, lain halnya dengan ahli waris yaitu orang yang berhak menerima warisan sesuai hukum (Fitriana, 2013). Menurut ajaran umum yang paling diutamakan dalam pewarisan yaitu penarikan hanya pada garis pria (patrilineal), di dalam hukum kekeluargaan Hindu kerap kali dikatakan sebagai kapurusan adalah posisi pria yang dominan dibanding perempuan. Sangat penting umumnya menjalani Pitra Puja bagi pemikul Dharma (kewajiban) yaitu melakukan pemujaan dan tanggung jawab terhadap leluhur, yang diikuti hak mendapatkan warisan, menggunakan, menjaga dan melindungi barang- barang pusaka. Tetapi ditemukan cara lain dalam meneruskan kehidupan keturunan mereka, yang mana pasangan suami istri yang memiliki anak perempuan tunggal yaitu mengusahakan membuat "Sentana Rajeg". Pihak perempuan menarik pihak suami keluar dari ikatan purusa. Oleh karena itu, posisi istri sebagai Purusa sedangkan posisi suami sebagai Pradana secara keagamaan dan hukum. Manfaat utama yaitu anak perempuan mendapatkan posisi sebagai Sentana Purusa dengan kata lain anak penerus keturunan di dalam keluarga.

Dalam hukum adat Bali wajib sekiranya dilakukan suatu penelitian tentang posisi hukum Anak Astra. Kedudukan hukum tersebut adalah hubungan antara hak dan kewajiban anak astra kepada orang tua. Penelitian ini bertujuan menjelaskan kedudukan Hukum Anak Astra setelah berlakunya Undang-Undang Nomor 1 Tahun 1974 tentang Perkawinan dan mendeskripsikan Hak Waris Anak Astra dalam Hukum adat Bali setelah orang tua biologisnya kawin sah.

\section{METODE PENELITIAN}

Penelitian ini menggunakan penelitian hukum normatif yaitu mengacu pada studi kepustakaan di bidang hukum dengan menggunakan pendekatan Perundang-Undangan (Bambang, 2002). Pengumpulan bahan hukum primer dan sekunder dilaksanakan melalui membaca dan menelaah peraturan perundang-undangan melalui teknik studi pencatatan dan studi dokumentasi. Teknik analisis menggunakan analisis bahan hukum secara interpretasi hukum dan argumentatif serta disajikan secara deskriptif analisis

\section{HASIL DAN PEMBAHASAN}

\section{Kedudukan Hukum Anak Astra Setelah Berlakunya Undang-Undang Nomor 1 Tahun 1974 tentang Perkawinan}

Ketentuan dalam Undang-Undang Nomor 1 Tahun 1974 dan Hukum adat maupun KUHPerdata anak bisa digolongkan menjadi anak sah dan anak tidak sah. Anak sah yaitu anak yang telah lahir ataupun tumbuh di suatu pernikahan. Namun, anak tidak sah yaitu anak yang telah lahir diluar pernikahan. Dikarenakan diperoleh ketidaksamaan pemikiran mengenai berlaku atau tidak ketentuan anak yang telah lahir diluar perkawinan dalam Undang-Undang Nomor 1 Tahun 1974, jadi diperoleh juga ketidaksamaan tentang macam-macam anak. Anak Astra (anak luar kawin) dalam Undang-undang Perkawinan Pasal 43 ayat (1) U dijelaskan bahwa: "anak yang dilahirkan di luar perkawinan 
hanya memiliki hubungan perdata terhadap ibu ataupun keluarga ibu", dan pasal 43 ayat (2) menyatakan bahwa "posisi anak dari luar pernikahan tersebut akan diurus kedalam Peraturan Pemerintah". Oleh karena itu, anak yang tidak sah cuma memiliki hubungan dengan ibu ataupun keluarga ibu sama halnya dengan hal mewaris. Perkara posisi anak telah diatur dalam Undangundang Perkawinan bab IX pasal 42 pasal 44. Sesuai Pasal 42, 43 UU Perkawinan dan pasal 100 KHI menyebutkan bahwa anak di luar pernikahan cuma memiliki hubungan hukum dengan ibunya ataupun keluarga ibunya sama halnya tentang mewarisi. Namun ketika orang tuanya melaksanakan pengesahan ataupun pengakuan berarti anak tersebut setara posisinya dengan anak sah. Anak sah pun bisa merubah posisi ahli waris dan mampu mewarisi dari orang tuanya.

Berdasarkan hukum adat sistem keturunan diprovokasi dengan struktur kekerabatan maupun kemasyarakatannya dimana tersusun oleh sistem matrilineal adalah sistem kekerabatan yang ditarik menurut garis ibu, sistem patrilineal (sistem kekerabatan yang ditarik menurut garis bapak), sistem parental maupun bilateral adalah sistem kekerabatan yang ditarik dari garis ayah dan ibu. Sistem pewarisan kolektif yaitu jika si ahli waris mendapatkan harta warisan dengan cara kolektif (bersama) dari pewaris yang tidak terbagi dengan cara seorangan (Dan \& Mansur, 2020). Menurut sistem tersebut si ahli waris tidak diperbolehkan mempunyai harta peninggalan secara pereroangan ataupun untuk sendiri. Sistem pewarisan mayorat adalah jika harta pusaka tidak dibagi dan cuma dikuasai oleh anak sulung, dimana hak untuk memakai, hak mengolah dan mumungut hasil tersebut dipegang seluruhnya oleh anak sulung sesuai hak dan kewajiban dalam mememlihara ataupun menjaga adiknya hingga adiknya mandiri.

Sistem pewarisan individu adalah bila harta warisan tersebut dikepah dan mampu diambil secara perorangan dengan "hak milik" yang berarti bahwa setiap ahli waris berhak menggunakan, menikmati serta mengolah hasil tersebut dan juga mentransaksikannya, terutama setelah pewaris meninggal. Berdasarkan hukum adat Bali, jika dihubungkan dengan sistem pewarisan, di Bali menganut sistem kekeluargaan patrilineal (menarik garis keturunan dari pihak ayah) artinya anak pria yang sah dan anak sah sesuai hukum adat saja yang mampu mewarisi harta peninggalan orang tua, beda halnya kalau anak wanita tak dapat mewaris. Namun terdapat satu pengecualian dalam suatu keluarga jika memiliki satu anak wanita lalu anak itu dapat mewarisi dikarenakan statusnya sudah beda menjadi status pria beda halnya dengan pria statusnya sudah beda menjadi status wanita, dengan demikian ia tak dapat mewarisi harta warisan dari bapak.

Pewarisan harta di Bali, warisan yang dapat dikepah oleh si ahli waris adalah harta warisan yang mampu dibagi seperti sawah, rumah, dan sebagainya. Beda halnya harta warisan yang tidak dapat dikepah yaitu tempat suci dan harta pustaka. Sedangkan menurut hukum adat di Bali, dari berbagai daerah justru berbeda dalam menentukan waris seorang anak yang lahir di luar perkawinan, hal ini sangat ditentukan dari kebiasaan masyarakat adat setempat, yang lebih dikenal dengan istilah desa Kala Patra dan desa Mawacara. Dengan adanya peristiwa seperti ini pihak korban maupun pihak keluarga yang bersangkutan mengadakan upacara serta penyelesaian dari masalah tersebut sebagai untuk menghindari musibah yang akan menimpa desa tersebut. Disini dari pihak keluarga, si wanita ini telah diupacarai yaitu mengawinkannya dengan sebuah keris pusaka, kemudian anak yang dikandungannya itu setelah lahir diupacarai dengan upacara ngutang buwu dan upacara dapetan, yang dipuput oleh seorang pemangku, namun pertanggungjawaban serta penyelesaian dari pihak lakilaki tampaknya belum jelas atau tidak ada, dan juga tuntutan dari masyarakat adat belum pernah ada sehingga masalah si anak dibiarkan begitu saja tanpa seorang ayah yang sah dan sampai sekarang si anak tinggal bersama ibunya dan keluarga ibunya, sampai sekarang berakibat anak luar kawin (anak astra).

\section{Hak Waris Anak Astra dalam Hukum adat Bali Setelah Orang Tua Biologisnya Kawin Sah}

Posisi anak astra mengingatkan dengan peraturan dalam hukum keluarga, dimana menyangkut pengakuan anak astra dan oleh karena itu memiliki peluang yang luas dengan hukum waris. Pengakuan kepada anak astra dilaksanakan oleh seorang dengan cara yang ditentukan dengan Undang-Undang bahwa anak tersebut, bapak dan ibu anak itu, seorang yang telah lahir diluar perkawinan. Pasal 280 KUHPerdata menyebutkan bahwa pengakuan yang dilaksanakan kepada anak yang dilahirkan diluar perkawinan timbullah hubungan perdata antara anak itu dengan bapak atau ibu dari anak itu. 
Dalam praktik pembuktian kepada tanak astra yang dilaksanakan oleh seorang pria (tidak bapak asli), anak astra yang dilaksanakan oleh seorang perempuan yang melahirkan anak itu. Hal tersebut dikarenakan catatan sipil tak dapat merealisasikan apakah pria itu memang bapak asli dari anak diluar pernikahan itu. Sebelum ditetapkannya Undang-Undang Perkawinan Nomor 1 Tahun 1974, pengakuan anak astra menurut KUHPerdata wajib dilaksanakan, jika ibu maupun ayah aslinya berkeinginan untuk mengadakan hubungan perdata dengan anak astra. Jadi status maupun posisi anak astra setara dengan anak sah dan juga korelasi perdata anak astra dengan ayah dalam hal hak waris yang mana anak astra memiliki hak mendapatkan warisan.

Mencermati anak luar kawin sebagaimana telah disebutkan di atas tidak tepat dan tidak adil manakala hukum menetapkan bahwa anak yang lahir dari suatu kehamilan karena hubungan seksual di luar perkawinan hanya memiliki hubungan dengan perempuan yang sebagai ibunya, maka dikeluarkannya Putusan MK No.46/PUU-VIII/2010 yang menyebutkan bahwa dengan memberi hak yang sama terhadap anak luar kawin dengan anak-anak yang lahir dalam perkawinan yang sah. Akan tetapi hal ini menimbulkan masalah, karena melegalkan hubungan seksual di luar perkawinan sehingga dapat berakibat maraknya hubungan seks bebas yang tidak jauh berbeda dengan binatang.

Berdasarkan Keputusan Mahkamah Konstitusi Nomor: 46/PUU-VIII/2010 pada tanggal 17 Februari 2012 hanya menguatkan kedudukan ibu dari si anak luar kawin dalam memintakan pengakuan kepada ayah biologis dari anak luar kawin tersebut, jika ayahnya tidak ingin melakukan pengakuan dengan sukarela terhadap anak luar kawin. Dengan diakuinya anak luar kawin oleh ayah biologisnya, maka pada saat itulah timbul hubungan perdata dengan si ayah biologisnya dan keluarga ayahnya. Jadi setelah adanya proses pengakuan kepada anak luar kawin itu, maka lahirlah hubungan perdata antara anak luar kawin tersebut dengan ayahnya yang telah diatur di dalam ketentuan Pasal 280 KUHPerdata menjelaskan "Jika adanya pengakuan anak dari luar pernikahan, terlahir korelasi perdata antara anak dan bapak maupun ibunya".

Masyarakat yang mempercayai sistem kekeluargaan patrilineal dalam hukum adat Bali yang dimana posisi pihak pria dominan terlihat dibandingkan posisi perempuan, apabila berlangsungnya pernikahan lalu bagian wanita yang hadir ke dalam keluarga pria dan bagian perempuan diduga telah bebas dari keluarga perempuan, begitu pula dengan anak yang nantinya muncul hendak hadir ke dalam keluarga bapak bukan ke dalam keluarga ibu. Jika pernikahan antara pembelai dengan kasta yang serupa terjadi, lalu tak akan jadi masalah, berbeda jika mempelainya berlainan kasta, jika pihak pria mempunyai kasta yang lebih tinggi jadi perempuan tesebut hendak terangkat derajatnya sedangkan bila pihak pria mempunyai kasta yang lebih rendah jadi pihak perempuan tersebut hendak turun menyesuaikan kasta si laki-laki. Oleh sebab itulah pihak keluarga besar si bapak berharap supaya pernikahan tersebut ditunggu hingga anak tersebut lahir kemudian pernikahan bisa dilakukan, yang menyebabkan derajat ibu tersebut naik tetapi anak yang lahir tak bisa mengikuti kasta si bapak, anak tersebut yang dikatakan sebagai Anak Astra.

Umat Hindu dalam bidang hukum kekeluargaan mempercayai sistem Kapurusan, dimana memiliki arti ikatan seorang dengan keluarganya bertitik berat dengan garis bapak, lanjut kakek (bapak dari bapak), serta tak mempedulikan garis ibu (Suhardi \& Untung, 2015). Berdasarkan sistem seperti ini, posisi anak pria dominan daripada kedudukan wanita. Penting yang dimaksud yaitu menjalankan Pitra Puja (pemujaan dan tanggung jawab kepada leluhur), memikul Dhana, yang diikuti dengan hak mendapatkan harta warisan dimana disebut dengan ahli waris. Tetapi berdasarkan adat Bali yang paling banyak berlaku yaitu kelompok Sapinda, yang artinya si ahli waris satu turunan pria yang ditarik lurus kebawah dan keatas adalah tersusun dari ahli waris utama yaitu anak laki - laki, ayah, cucu, kerabat dan kakek.

Berdasarkan hasil wawancara yang dilakukan pada tanggal 11 februari 2020 Bendesa Adat dari desa Adat Sidemen Karangasem yaitu Nyoman Windia dalam hukum adat Bali hak waris anak astra set orang sudah tua aslinya menikah opini beliau dalam hukum adat Bali adalah "Setelah anak astra itu lahir dan dilakukannya suatu perkawinan sah maka hak dan statusnya menurut ayahnya (purusa) dalam hukum adat Bali, jika kedua orang tua biologisnya kawin sah maka anak tersebut tidak lagi disebut anak astra melainkan anak sah dalam hukum adat Bali." Dari Hasil wawancara tersebut dapat ditegaskan bahwa orang tua biologis yang sudah melakukan Perkawinan secara sah maka hak yang dimiliki oleh anak astra akan sama seperti anak sah yang sesuai adat Bali yang mengikuti sang ayah begitu pula hak dari anak astra tersebut terhadap orang tua biologisnya, di Bali 
jika kedua orang tua biologis melakukan Perkawinan yang telah memiliki anak astra harus disaksikan oleh 3 saksi yaitu Saksi Upakara, Saksi Manusa, Saksi Widhi.

\section{SIMPULAN DAN SARAN}

\section{Simpulan}

Berdasarkan hasil analisis data, dapat disimpulkan bahwa Anak luar pernikahan yang mana sudah dijelaskan tak tepat dan tak adil bila hukum menetapkan bahwa anak yang lahir dari suatu kehamilan karena hubungan seksual di luar pernikahan Cuma mempunyai hubungan dengan perempuan yang sebagai ibunya, lalu dikeluarkannya Putusan Mahkamah Konstitusi Nomor : 46/PUU-VIII/2010 pada tanggal 17 Februari 2012 yang menguatkan posisi ibu dari anak luar perkawinan itu dalam memintakan pengakuan kepada bapak aslinya jika bapak tersebut tak ingin mengakui secara ikhlas terhadap anak tersebut, yag kedua Dalam Hukum adat Bali adapun hak Anak Astra setelah Orang Tua Biologis anak tersebut kawin secara sah adalah setelah anak astra itu lahir dan dilakukannya suatu perkawinan sah maka hak dan statusnya menurut ke ayahnya (purusa) dalam hukum adat di Bali, jika kedua orang tua biologis anak tersebut kawin secara sah maka anak tersebut tidak lagi disebut anak astra melainkan anak sah dalam hukum adat Bali.

\section{Saran}

Dari hasil penelitian di atas, adapun saran yang diberikan yaitu diharapkan kepada Ketua Banjar Desa Adat Sidemen sebagai aparatur desa agar dapat menerima keberadaan seorang Anak Astra sebagaimana dia manusia biasa yang juga harus diberikan hak atau kesempatan membuktikan bahwa dirinya juga dapat berguna dalam berbangsa maupun bernegara yang baik tidak boleh dipandang dalam segi Anak Astra saja tetapi juga bahwa dia adalah warga masyarakat yang nantinya apabila nantinya ia diberikan hak untuk disahkan menjadi anak sah, yang kdua diharapkan kepada lembaga masyarakat seperti Parisada Hindu Hindu Dharma, yang menangani permasalahan diruang lingkup Adat Bali sebagai payung umat hendaknya berfungsi supaya umatnya mampu menikmati keadilan maupun kedamaian di kehidupannya, perkara anak astra itu diharapkan dibuat aturan yang lebih tegas dan jelas tentang kedudukan anak astra tersebut. Aturan yang dibuat harus sesuai dengan hukum positif dan dibuat tertulis yang sesuai dengan hak asasi anak astra.

\section{DAFTAR PUSTAKA}

Bambang, W. (2002). Penelitian Hukum dalam Praktek. Jakarta: Sinar Grafika.

Dan, D. F., \& Mansur, I. A. (2020). Dinamika Hukum Waris Adat di Masyarakat Bali Pada Masa Sekarang. Media Iuris, 3(2), 119-132.

Fitriana. (2013). Perbandingan Pembagian Warisan untuk Janda Menurut Kitab Undang-Undang Hukum Perdata dan Hukum Waris Islam. Jurnal Ilmu Hukum Legal Opinion, 1(3), 1-10.

Hadikusuma.H, H. (1996). Hukum Waris Indonesia menurut: Perundang Hukum Adat, Hukum Agama HinduIslam. Bandung: PT Cita Aditya Bakti.

Saragih, D. (1984). Pengantar Hukum Adat Indonesia. Bandung: Tarsito.

Soekanto, S. (1986). Kedudukan Janda Menurut Hukum Waris Adat. Jakarta: Ghalia Indonesia.

Soeripto. (1973). Beberapa Bab Tentang Hukum Adat Waris Bali. Jember: UNEJ.

Suhardi, K. H., \& Untung. (2015). Dinamika Perkawinan Adat Bali: Status dan Kedudukan Anak Sentana Rajeg Menurut Hukum Adat dan Hukum Hindu. Dharmasmrti, 13(26), 1-135. 